\title{
Group psychological counselling as a form of prevention of adolescent addictive behaviour
}

\author{
Grupowe poradnictwo psychologiczne jako forma profilaktyki \\ zachowań uzależnieniowych młodzieży
}

\author{
${ }^{1}$ Al-Farabi Kazakh National University, Almaty, Republic of Kazakhstan \\ ${ }^{2}$ Kazakh National Women's Teacher Training University, Almaty, Republic of Kazakhstan \\ ${ }^{3}$ M. Auezov South Kazakhstan University, Shymkent, Republic of Kazakhstan \\ ${ }^{4}$ Rehabilitation Clinic"Reinhardshöhe,"Hessen, Germany \\ ${ }^{5}$ Samara State University of Social Sciences and Education, Samara, Russian Federation \\ Correspondence: Sveta Berdibayeva, 050038, Kazakhstan, Almaty, Al-Farabi Avenue 71, tel.: 87772374977, e-mail: berdibayeva.sveta1@mail.ru
}

Abstract This article provides an analysis of domestic and foreign literature on the concept of "adolescent addictive behaviour," summarises its scientific understanding, and outlines the mechanisms of the emergence of addictive behaviour and psychological characteristics of adolescents exhibiting addictive behaviour. The study presents a review of modern research on the problems of Internet-, food-, and alcohol addictions. The review includes Russian, Kazakh and international literature on the psychological prevention of adolescent addictive behaviour. The concept of the "psychological prevention of adolescent addictive behaviour" is disclosed, and the principles and objectives of preventive work with adolescents prone to addictive behaviour are defined. A set of diagnostic techniques is proposed to study the predilection of adolescents to addictive behaviour. The article reveals the content and effectiveness of the programme for the psychological prevention of adolescents' predisposition to addictive behaviour by means of group psychological counselling. The authors describe the course of experimental work on the study of adolescents' predisposition to addictive behaviour, present the testing of the developed psychological programme, and demonstrate the effectiveness of adolescents' group counselling to prevent their addictive behaviour. The results of the study confirm the authors' hypothesis that the use of group forms of psychological counselling is effective in psychological prevention, as it relies on the activity of adolescents. The results of the study contribute to the development of preventive pedagogy and psychology, and the improvement of the modern system of anti-alcohol and anti-drug education of adolescents. The study findings can be also used in educational institutions in advisory and remedial work with adolescents.

Keywords: adolescence, deviant behaviour, addiction, prevention of addictive behaviour, psychological counselling

Streszczenie W wacy dokonano analizy piśmiennictwa krajowego i zagranicznego dotyczącego zagadnienia zachowań nałogowych młodzieży. Podsumowano stan wiedzy naukowej w tej dziedzinie oraz nakreślono mechanizmy powstawania uzależnienia i profil psychologiczny młodzieży przejawiającej takie zachowania. Autorzy dokonują przeglądu współczesnych badań poświęconych problematyce uzależnienia od internetu, jedzenia i alkoholu. Przegląd obejmuje piśmiennictwo rosyjskie, kazachskie i międzynarodowe na temat profilaktyki zachowań uzależnieniowych młodzieży. W pracy szczegółowo przedstawiono pojęcie „psychologicznej profilaktyki zachowań nałogowych młodzieży” oraz określono zasady i cele pracy profilaktycznej z młodzieżą wykazującą skłonność do zachowań uzależnieniowych. Zaproponowano także zestaw technik diagnostycznych do badania skłonności młodzieży do zachowań uzależnieniowych. Opisano treść i skuteczność programu profilaktyki psychologicznej u młodzieży z predyspozycją do zachowań nałogowych bazującego na grupowym poradnictwie psychologicznym. Autorzy opisują przebieg eksperymentalnego programu badającego predyspozycje młodzieży do zachowań uzależnieniowych oraz analizują skuteczność opracowanego programu wsparcia psychologicznego. Wskazują również na skuteczność grupowego poradnictwa młodzieży jako narzędzia zapobiegania zachowaniom uzależnieniowym. Wyniki badania potwierdzają sformułowaną przez autorów hipotezę, że grupowe formy poradnictwa psychologicznego stanowią skuteczną formę profilaktyki uzależnień dzięki wykorzystaniu aktywności młodzieży. Otrzymane wyniki mogą przyczyniać się do rozwoju wiedzy pedagogicznej i psychologicznej w zakresie profilaktyki oraz tworzenia nowoczesnego systemu edukacji antyalkoholowej i antynarkotykowej wśród młodzieży. Mogą być również przydatne w placówkach oświatowych podczas pracy wychowawczej i terapeutycznej z młodzieżą. 


\section{INTRODUCTION}

$\mathrm{T}$ he problem of addictive behaviour has repeatedly been the subject of research by various specialists including psychologists, social workers, teachers, sociologists, psychiatrists, etc. It remains relevant for many economically developed countries. In the $21^{\text {st }}$ century, more than a hundred studies have been published on the prevalence of behavioural addiction in the world. The prevalence of Internet addiction, for example, varies from $0.8 \%$ in Italy to $26.7 \%$ in Hong Kong (Chukhrova, 2014). The dependence problem becomes especially urgent in the context of the COVID-19 pandemic, when people (and adolescents in particular) are forced to be self-isolated.

In Russia, the number of drug addicts is currently more than 500 thousand people, $70 \%$ of whom are under 25 years of age. Expert estimates show that the actual number is 5-8 times higher (about 4 million people) (Battakova et al., 2015). According to Semenova (2012), in Russia there are 2-2.5 million drug addicts. The average age of drug addicts in Russia, according to statistics, is 15-17 years, and there is an increase in the percentage of drug use by children aged 9-13 years. The prevalence of addictive behaviour in the Republic of Kazakhstan has been discussed by various researchers (e.g. Battakova et al., 2015; Morozova, 2016; Satayeva, 2013). Studies conducted by these authors show regions where the extent of addiction is higher, present the dynamics of the incidence of drug addiction in the Republic of Kazakhstan, and analyse the dynamics of the number of mental and behavioural disorders associated with the use of psychoactive substances. In the context of different types of addictive behaviour, it is worth noting that the Republic of Kazakhstan in terms of alcohol consumption ranks 34 out of 188 countries of the world (10.96 litres of alcohol per capita), and is the first among the Central Asian countries (Abdrakhmanova et al., 2019; Bibekova et al., 2020). According to the 2016 data, the number of children who drink alcohol in Kazakhstan increased 10-fold in three years, and the number of drinking adolescents doubled (Morozova, 2016). At the same time, though, in some countries, alcohol consumption among children and adolescents is decreasing (Ridder City Portal, 2019). For example, the World Health Organization (WHO) (2020) reports a decrease in the number of schoolchildren who have tried alcohol in Russia. According to the WHO Health Behavior in School-Aged Children survey (World Health Organization Collaborative Cross-National Survey, 2020), the number of school-aged children who have tried alcohol at least once has declined in Russia. A report published by the World Health Organization in 2018 analyses data on adolescent drinking collected over a 12-month period. The report reveals a decline in alcohol consumption among young people in Europe. An analysis of alcohol dependence is presented in the studies by Chung et al. (2018) and Chen et al. (2015). The problem is also explored in sufficient
Food addiction is analysed by such authors as Cottone et al. (2019) and Schulte et al. (2018). The development of food addiction and subsequent obesity can be a result of physical inactivity under the conditions of self-isolation while maintaining the usual diet. A more dangerous option for the development of food addiction is getting used to eating fast foods. The main types of food disorders include anorexia nervosa and bulimia nervosa. According to Mikhaylova and Shtrakhova (2018), they share the following parameters: concern with controlling body weight; distortion of body image; and change in the value of food in the hierarchy of values. The construct of food addiction has received increased attention and has been proposed as a mental disorder. There is some evidence that supports the inclusion of food addiction in the psychiatric nosology; however, the construct has not as yet been sufficiently validated for inclusion (Wenzel et al., 2020).

Studies by Throuvala et al. (2019), Salarvand et al. (2018), Ansari et al. (2017) and Rahardjo (2019) address the problem of Internet addiction. Long-term use of the Internet often leads to such negative consequences as narrowing the range of interests, moving away from reality into the virtual world, and developing computer and Internet addiction (Drepa, 2009). One of the first studies of the phenomenon of Internet dependence was conducted by the clinical psychologists Young and de Abreu (2011), who in 1994 developed a special questionnaire to study the degree of people's addiction to the Internet. One should also mention the works of the psychiatrist Goldberg et al. (1998), who in 1996 proposed the term "Internet addiction" to describe an unreasonably long, possibly pathological, use of the global information network, as well as the works of Griffiths (Pontes et al., 2015), which present research on Internet-dependent behaviour.

The problem of drug addiction in Kazakhstan was and remains as relevant as alcoholism (Morozova, 2016). Synthetic drugs have flooded the market for psychoactive substances. As Suleimenova, the chief doctor of the city drug rehabilitation centre in Almaty, pointed out, "more than 7.5 thousand people dependent on psychoactive substances have been registered in the city of Almaty. About 2 thousand of them use various types of drugs, including synthetic ones, and the rest - alcohol. To get a reliable picture of the actual situation, statistical indicators should be multiplied at least 10-11 times" (Information Agency "Kokshetau Asia," 2017). Speaking about modern forms of addictive behaviour, Kaliyev (2019) draws attention to the fact that "two or three years ago, Spice came to Kazakhstan [Spice being a smoking mixture, the active ingredients of which are synthetic analogues of tetrahydrocannabinol, the main active ingredient in marijuana, such as CP 47,497 and JWH-018. The synthetic cannabinoids which are the active substances in Spice are banned in most countries of the world, including Russia, USA, and many EU countries]. Two or three doses of this 'chemistry' in smoking mixtures cause dependence with a clear withdrawal syndrome." 
As for non-chemical addictions, Okuneva and Darbayev (2015) noted that $80 \%$ of adolescents in Kazakhstan suffer from computer addiction. At the same time, they reasonably believe that "with the growth of computerisation in all countries, including Kazakhstan, the number of people with Internet addiction will increase, especially among students” (Okuneva and Darbayev, 2015).

There are different types of addictions: chemical, nonchemical (such as video game addiction, gambling addiction), and an intermediate group that includes food addiction. Addressing the issue of chemical addictions, Kulakov (2003) gives the following definition of addictive behaviour: "one of the forms of destructive behaviour which is characterised by the desire to escape from reality through changing one's mental state by taking any substances.” As indicated by Lipunova (2016), "an escape from reality in the form of a 'cop-out' often consists in a teenager concentrating on a narrowly focused field of activity (often disharmonious and personality-destroying), ignoring all other areas of activity." A broader definition is found in the studies conducted by Mendelevich (2007): "addictive behaviour is one of the types of deviant behaviour with the formation of a person's desire to escape from reality through artificially changing one's mental state by taking certain substances or by permanently fixing attention on certain types of activities in order to develop and maintain intense emotions." An analysis of the personal qualities of adolescents prone to addictive behaviour shows that they can be characterised by low self-esteem; high personal anxiety; lack of social competence; low social intelligence, and conformity in communication (Yarysheva, 2012).

The empirical research conducted by Ivanov (2013) shows that the significant socio-psychological determinants of the formation of addictive behaviour among adolescents include the accentuation of character, low self-esteem, and disharmonious style of family education.

As part of our research, we are interested in the primary and secondary prevention of adolescent addictive behaviour, carried out both in individual and group forms on the basis of various programmes and methods proposed in domestic and foreign psychological practice. We set the following tasks:

1. to identify the peculiarities of the mental states of atrisk adolescents;

2. to develop a programme of group psychological counselling based on the identified peculiarities of the mental states of adolescents, and aimed at the psychological prevention of their predisposition to addictive behaviour through self-awareness, self-education, and development of a healthy lifestyle;

3. to show that the group form of psychological counselling is one of the most effective psychological means of preventing adolescents' predisposition to addictive behaviour.

The psychological prevention of addictive behaviour in adolescence is of particular importance, since it is at this age that important personality traits are being formed such as striving for self-development and self-awareness, self-interest, self-observation, reflection, and morality (Shilova, 2004). The prevention of addictive behaviour is targeted, as a rule, at various areas of the adolescent's life: family, educational environment, and social life in general (Krasnova, 2017). The psychological counselling of adolescents has its own specific characteristics and is carried out in various forms including individual psychological counselling and group psychological counselling (selection by age, type of addiction and homogeneity of the root cause of addiction) (Krasnova, 2017).

The psychological counselling of adolescents who are prone to addictive behaviour in the school setting is more often individual in nature and is provided at the request of teachers, administration, and parents. As indicated by Rozhkov and Kovalchuk (2004), the school psychologist in the process of counselling adolescents may encounter temporary and permanent forms of deviant behaviour (by the duration of deviations), as well as stable and unstable forms (by the criterion of mono- or polyphenomenological forms). Deviations can be conscious and unconscious (by the criterion of awareness), structured and unstructured (by the criterion of organisation), spontaneous and planned (by the criterion of the goal), expansive and non-expansive (by the level of intrusion into the life of the surrounding people), selfish and altruistic (by the focus on interests) (Rozhkov and Kovalchuk, 2004).

Regardless of the form of manifestation of deviant (addictive) behaviour, there a violation of the adolescent's interaction with reality is observed. Due to a lack of formation of behavioural acts, adolescents can apply non-constructive ways of interacting with the surrounding reality, such as opposition to reality, painful confrontation with reality (when the surrounding world is perceived as hostile due to the subjective distortion of its perception and understanding), and escape from reality (which can be regarded as a manifestation of adolescent weakness and ignoring the surrounding reality). The most constructive type of the adolescent's interaction with reality is adaptation, which indicates the development of their adaptive system.

According to Glebova (2011), the main objectives of preventive work with adolescents who are prone to addictive behaviour are as follows:

1. development of a healthy lifestyle and functional behavioural strategies;

2. creation of conditions for open, trusting communication, perception of information, and a creative atmosphere;

3. raising awareness about the effects and consequences of substance abuse, about the causes and forms of abuserelated diseases, about different ways to recovery, and about the links between substance abuse and other forms of self-destructive behaviour, personality characteristics, communication, stress, and ways to cope with it;

4. development of adolescents' personal resources: formation of self-concept; formation of their own system 
of values, goals and attitudes; stimulation of the ability to make independent choices, control their behaviour, solve simple and complex life problems, be able to evaluate a particular situation and their capacity to control it, be able to analyse their physical and mental state, self-regulation skills; formation of the ability to communicate with others, understand their behaviour, empathise with them and, as necessary, provide them with social and psychological support; stimulation of individual needs in obtaining and providing support to others;

5. formation of strategies and behavioural skills aimed at the development of skills for a healthy lifestyle.

The psychological prevention of addictive behaviour involves a number of important stages, such as the diagnostic and awareness-raising stages, as well as personal growth training with elements of adjusting adolescents' individual personality traits and behaviours. The preventive forms of work can be carried out in both individual and group forms of psychological counselling (Krasnova, 2017).

A literature review presented by Krasnova (2017) shows that the group form of work is the most attractive option for adolescents. Therefore, the psychologist can conduct group forms of psychological counselling with adolescents, potentially involving model situations, creative tasks, training exercises aimed at finding alternatives to deviant (addictive) behaviour, as well as exercises leading to the expansion of opportunities in social life due to desistance from deviant behaviour.

An important task of group counselling for adolescents prone to addictive behaviour is to enhance the ability to navigate their own and other people's emotions, and to develop their sense of empathy. As noted by Bedulina (2008), "adolescents have such a poor emotional world that they are not able to understand what kind of pain they cause to others by such behaviour. They are sure that the entire world is as emotionally poor as their own."

One of the important tasks solved in the process of group psychological counselling is to organise the activities of adolescents that provide an alternative to addictive behaviour. This form of work is associated with the idea of the substitution effect for addictive behaviour. It is implemented in almost all the programmes providing psychological assistance to adolescents with deviant behaviour.

Group counselling creates conditions contributing to the successful social and psychological adaptation of adolescents in the "social risk" group. Adolescents develop their constructive communication and self-regulation skills, learn constructive ways out of difficult, stressful situations, and develop a positive self-attitude. Various games and exercises help to find constructive ways of reacting in situations of interpersonal interaction, including conflicts, and foster self-analysis and reflection skills.

The basic principles of working with adolescents who are prone to addictive behaviour in the framework of psychological counselling are as follows:
- positive feedback, as most adolescents prone to addictive behaviour need emotional support;

- continuity of psychological support for adolescents prone to addictive behaviour.

\section{MATERIALS AND METHODS}

An experimental study was conducted, aimed at verifying the hypothesis formulated in the study: the group form of psychological counselling for adolescents is one of the effective means of psychological prevention of adolescent addictive behaviour. The experimental study was carried out in the Almaty secondary school No. 138. The sample included 54 pupils from the $8^{\text {th }}$ grades aged $13-15$ years: 8 A grade 26 pupils, $8 \mathrm{~B}$ grade -28 pupils.

The psychodiagnostic set of methods was presented by the following techniques. Oryol's "Methods for the diagnosis of adolescents' predisposition to deviant behaviour" were used to identify at-risk adolescents, i.e. those who are prone to addictive behaviour (Prokhorov, 2004). Accordingly, two groups of subjects were formed: an experimental group and a control group. The experimental group included 12 adolescents (8A grade), and the control group - 9 adolescents (8B grade). Then, in order to determine the forms of psychological preventive work, a comprehensive survey was conducted among at-risk adolescents, using the following tests: Thomas's "Methodology of conflict behaviour strategies" (Karelin, 2007), Morosanov's questionnaire "Style of behaviour self-regulation" (Morosanova, 2001), Ayzenk's test "Self-assessment of mental states" (Prokhorov, 2004). The presented set of psychodiagnostic methods, according to Krasnova (2017), makes it possible to create a programme for the psychological prevention of the use of psychoactive substances by adolescents at the behavioural, cognitive, emotional, and physical levels.

The study also used mathematical statistics methods, so that the findings obtained could be statistically processed. The statistical differences of changes in the course of the experimental study were determined using the analogue criterion $\varphi^{\star}$ - Fisher's angular transformation - concordance of event frequency.

\section{RESULTS AND DISCUSSION}

At the stage of primary diagnosis, at-risk adolescents were identified using Oryol's "Methods for the diagnosis of adolescents' predisposition to deviant behaviour" (see Tab. 1, Figs. 1 and 2). At the next stage, a programme of the group form of psychological counselling was compiled and tested. The programme was implemented among the adolescents from the experimental group in the form of group counselling. The adolescents from the control group were individually consulted on the topics discussed with the adolescents from the experimental group during group counselling. The purpose of the programme is the psychological prevention of adolescents' predisposition to addictive behaviour 


\begin{tabular}{|c|l|c|c|}
\hline No. & Scale & $\mathbf{8 A ~ g r a d e ~ p u p i l s ~ ( \% ) ~}$ & 8B grade pupils (\%) \\
\hline 1 & Scale of setting for socially desirable answers & 10 & 12 \\
\hline 2 & Scale of predisposition to violate norms and rules & 23 & 21 \\
\hline 3 & Scale of predisposition to addictive behaviour & 34 & 32 \\
\hline 4 & Scale of predisposition to self-harm and self-destructive behaviour & 42 & 21 \\
\hline 5 & Scale of predisposition to aggression and violence & 42 & 39 \\
\hline 6 & Scale of the volitional control of emotional reactions & 28 & 18 \\
\hline 7 & Scale of predisposition to delinquent behaviour & 23 & 16 \\
\hline
\end{tabular}

Tab. 1. Diagnostic results of adolescents' predisposition to addictive behaviour by Oryol's methods

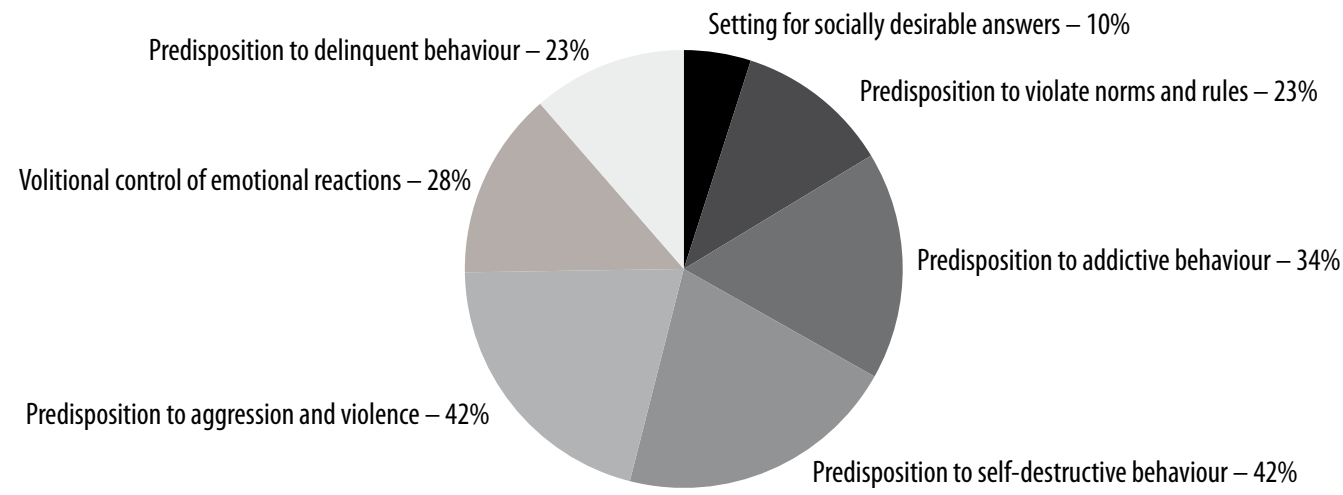

Fig. 1. Diagnostic results of the predisposition of 8 A grade pupils to addictive behaviour by Oryol's methods

through self-knowledge and self-education, and the development of healthy lifestyle skills.

The tasks of the programme are as follows:

1. to develop a healthy lifestyle, highly functional behavioural strategies, and personal resources that prevent substance abuse;

2. to create conditions for open, trusting communication, perception of information, and a creative atmosphere in the process of interaction;

3. to form ideas about the effects and consequences of substance abuse, and highlight links between drug abuse and other forms of self-destructive behaviour, personality traits, communication, stress, and ways to cope with it;
4. to develop the ability to make independent choices, be able to say no, bear responsibility for oneself, for one's actions and one's own choices, solve simple and complex life problems, and adequately accept the individual self;

5. to develop the ability to control emotions, behaviour and life, to learn the methods of self-regulation;

6. to learn the skills of cooperation, partnership, establishing contacts with other people, accepting others and providing psychological and social support;

7. to learn the ways of constructive conflict resolution, choosing the most appropriate strategy for behaviour in a conflict.

The programme consists of 3 blocks, each of which has a certain number of lessons and one final lesson.

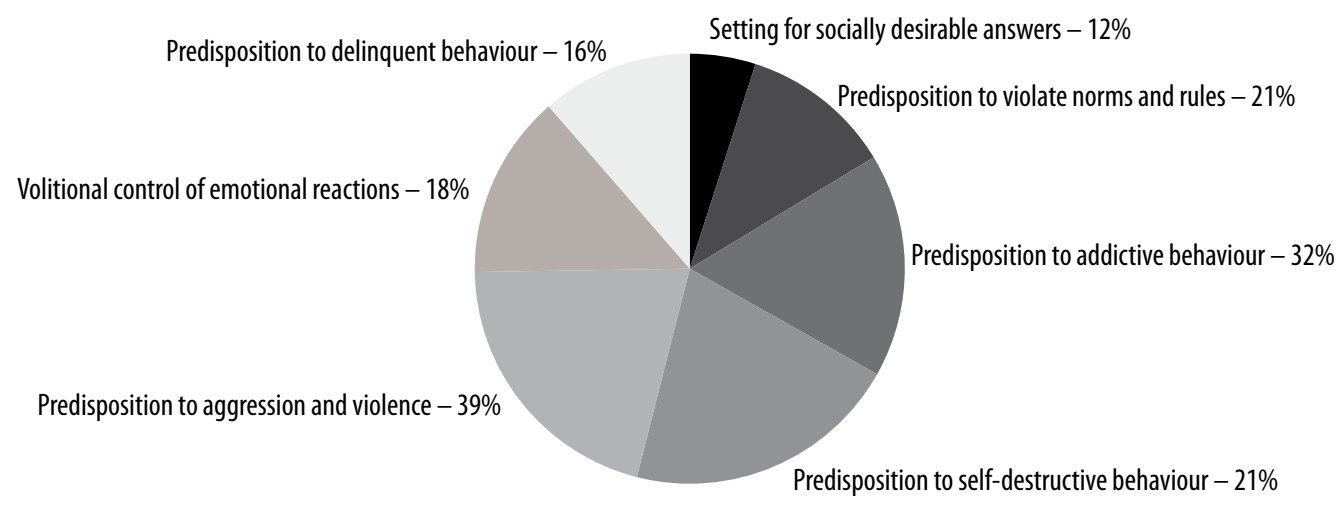

Fig. 2. Diagnostic results of the predisposition of $8 B$ grade pupils to addictive behaviour by Oryol's methods 


\begin{tabular}{|c|c|c|c|c|c|c|}
\hline \multirow[b]{2}{*}{ No. } & \multirow[b]{2}{*}{ Scale } & \multicolumn{3}{|c|}{ Experimental group } & \multicolumn{2}{|c|}{ Control group } \\
\hline & & $\begin{array}{c}\text { Before the programme } \\
\text { implementation } \\
{[\%]} \\
\text { (hereinafter - before) }\end{array}$ & $\begin{array}{c}\text { After } \\
\text { the program } \\
\text { implementation } \\
{[\%]} \\
\text { (hereinafter - after) }\end{array}$ & $\begin{array}{c}\text { Concordance } \\
\text { of event frequency } \\
\text { (hereinafter - CEF) }\end{array}$ & $\begin{array}{c}\text { Before the programme } \\
\text { implementation } \\
{[\%]} \\
\text { (hereinafter - before) }\end{array}$ & $\begin{array}{c}\text { After } \\
\text { the program } \\
\text { implementation } \\
\text { [\%] } \\
\text { (hereinafter - after) }\end{array}$ \\
\hline 1 & Competition & 34 & 10 & $p=0.004$ & 44 & 42 \\
\hline 2 & Cooperation & 0 & 38 & $p=0.003$ & 0 & 1 \\
\hline 3 & Compromise & 8 & 22 & $p=0.008$ & 11 & 12 \\
\hline 4 & Avoidance & 25 & 12 & $p=0.009$ & 34 & 33 \\
\hline 5 & Adaptation & 33 & 18 & $p=0.008$ & 11 & 12 \\
\hline
\end{tabular}

Tab. 2. Diagnostic results of adolescents' behavioural patterns in conflict situations by Thomas's "Methodology of conflict behaviour strategies" before and after the implementation of the experimental programme

\begin{tabular}{|c|c|c|c|c|c|c|}
\hline \multirow[b]{2}{*}{ No. } & \multirow[b]{2}{*}{ General level of self-regulation } & \multicolumn{3}{|c|}{ Experimental group } & \multicolumn{2}{|c|}{ Control group } \\
\hline & & $\begin{array}{c}\text { Before } \\
\text { [\%] }\end{array}$ & $\begin{array}{c}\text { After } \\
{[\%]}\end{array}$ & CEF & $\begin{array}{c}\text { Before } \\
{[\%]}\end{array}$ & $\begin{array}{c}\text { After } \\
{[\%]}\end{array}$ \\
\hline 1 & Low level & 50 & 6 & $p=0.002$ & 45 & 40 \\
\hline 2 & Medium level & 42 & 66 & $p=0.006$ & 45 & 50 \\
\hline 3 & High level & 8 & 28 & $p=0.009$ & 10 & 10 \\
\hline
\end{tabular}

Tab. 3. Diagnostic results of adolescents' self-regulation by Morosanov's questionnaire "Style of behaviour self-regulation" before and after the implementation of the experimental programme

The generalising stage included a repeated diagnostic procedure, a comparative analysis of the results before and after the implementation of the experimental programme, as well as statistical processing of the data and their interpretation.

Tabs. 2-4 present the results of the primary and repeated diagnosis.

The results obtained indicate that the implementation of the programme for the psychological prevention of adolescents' predisposition to addictive behaviour by means of the group form of psychological counselling helped to improve the overall emotional background of adolescents. This was facilitated by various active teaching methods, such as games and art-based therapeutic methods and discussions, which were widely used during the implementation of the programme.

According to the results of the statistical analysis, no significant differences were revealed in the control group.

\begin{tabular}{|c|c|c|c|c|c|c|}
\hline \multirow[b]{2}{*}{ No. } & \multirow[b]{2}{*}{ Scale, levels } & \multicolumn{3}{|c|}{ Experimental group } & \multicolumn{2}{|c|}{ Control group } \\
\hline & & $\begin{array}{c}\text { Before } \\
\text { [\%] }\end{array}$ & $\begin{array}{c}\text { After } \\
{[\%]}\end{array}$ & CEF & $\begin{array}{c}\text { Before } \\
\text { [\%] }\end{array}$ & $\begin{array}{c}\text { After } \\
\text { [\%] }\end{array}$ \\
\hline \multicolumn{7}{|c|}{ Anxiety } \\
\hline 1 & High level & 34 & 12 & $p=0.005$ & 33 & 31 \\
\hline 2 & Medium level & 33 & 45 & $p=0.008$ & 55 & 58 \\
\hline 3 & Low level & 33 & 43 & & 12 & 11 \\
\hline \multicolumn{7}{|c|}{ Frustration } \\
\hline 1 & High level & 42 & 18 & $p=0.004$ & 33 & 30 \\
\hline 2 & Medium level & 33 & 47 & $p=0.007$ & 45 & 47 \\
\hline 3 & Low level & 25 & 35 & & 22 & 23 \\
\hline \multicolumn{7}{|c|}{ Aggressiveness } \\
\hline 1 & High level & 42 & 8 & $p=0.003$ & 44 & 42 \\
\hline 2 & Medium level & 42 & 53 & & 44 & 46 \\
\hline 3 & Low level & 16 & 39 & $p=0.007$ & 12 & 12 \\
\hline \multicolumn{7}{|c|}{ Rigidity } \\
\hline 1 & High level & 17 & 6 & & 12 & 11 \\
\hline 2 & Medium level & 58 & 59 & & 33 & 33 \\
\hline 3 & Low level & 25 & 33 & $p=0.008$ & 55 & 56 \\
\hline
\end{tabular}

Tab. 4. Diagnostic results of the level of self-assessment of adolescents' mental states by Ayzenk's test "Self-assessment of mental states" before and after the implementation of the experimental programme 


\begin{tabular}{|c|l|c|c|c|c|c|}
\hline \multirow{2}{*}{ No. } & Scale & \multicolumn{2}{|c|}{ Experimental group } & \multicolumn{2}{c|}{ Control group } \\
\cline { 2 - 7 } & $\begin{array}{c}\text { Before } \\
{[\%]}\end{array}$ & $\begin{array}{c}\text { After } \\
{[\%]}\end{array}$ & $\begin{array}{c}\text { CEF } \\
\text { Before } \\
{[\%]}\end{array}$ & $\begin{array}{c}\text { After } \\
{[\%]}\end{array}$ \\
\hline 1 & Scale of setting for socially desirable answers & 10 & 3 & & 12 & 14 \\
\hline 2 & Scale of predisposition to violate norms and rules & 23 & 5 & $p=0.004$ & 21 & 20 \\
\hline 3 & Scale of predisposition to addictive behaviour & 34 & 3 & $p=0.002$ & 32 & 32 \\
\hline 4 & Scale of predisposition to self-harm and self-destructive behaviour & 42 & 10 & $p=0.002$ & 21 & 19 \\
\hline 5 & Scale of predisposition to aggression and violence & 42 & 7 & $p=0.003$ & 39 & 43 \\
\hline 6 & Scale of the volitional control of emotional reactions & 28 & 38 & & 18 & 20 \\
\hline 7 & Scale of predisposition to delinquent behaviour & 23 & 2 & $p=0.005$ & 16 & 18 \\
\hline
\end{tabular}

Tab. 5. Diagnostic results of adolescents' predisposition to addictive behaviour by Oryol's "Methods for the diagnosis of adolescents' predisposition to deviant behaviour" before and after the implementation of the experimental programme

The results of the diagnosis of adolescents' predisposition to addictive behaviour by Oryol's "Methods for the diagnosis of adolescents' predisposition to deviant behaviour" before and after the implementation of the experimental programme are presented in Tab. 5.

The number of adolescents with an increased predisposition to addictive behaviour significantly decreased:

- at the time of the initial study, a high level of predisposition to addictive behaviour was observed in $34 \%$ of adolescents, and after conducting the experimental programme - in only $3 \%$;

- before the programme implementation, $23 \%$ of adolescents had a predisposition to delinquent behaviour, after - $2 \%$;

- before the programme implementation, $23 \%$ of adolescents had a predisposition to violate norms and rules, after $-5 \%$;

- initially, $42 \%$ of adolescents had a predisposition to aggression and violence, after the programme implementation - only $7 \%$ of adolescents.

The results of the diagnosis of adolescents' predisposition to addictive behaviour in the experimental and control groups

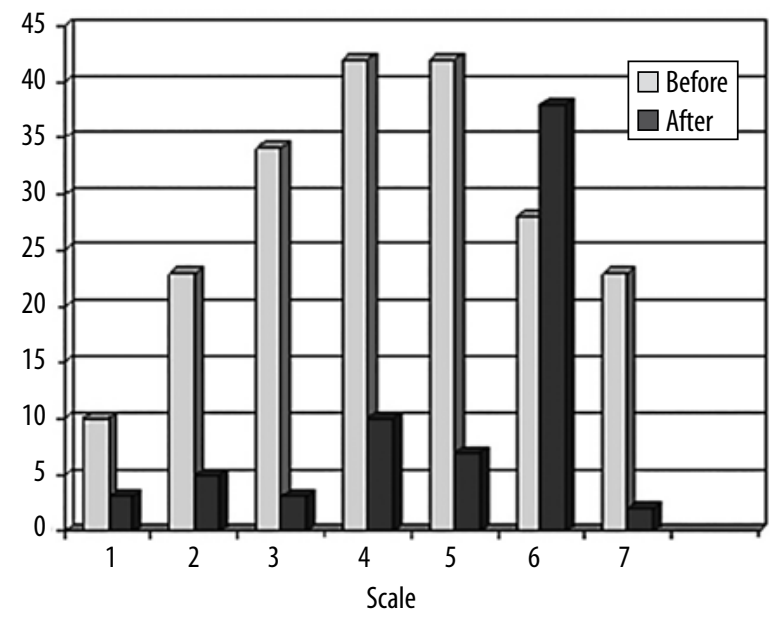

Fig. 3. Diagnostic results of adolescents' predisposition to addictive behaviour in the experimental group by Oryol's "Methods for the diagnosis of adolescents' predisposition to deviant behaviour" before and after the implementation of the experimental programme before and after the implementation of the experimental programme are presented in Figs. 3 and 4.

The experimental study thus confirmed the effectiveness of the programme for the prevention of adolescents' predisposition to addictive behaviour through group counselling. The adolescents showed a significant decrease in addictive behaviour and started to form highly effective behavioural strategies and personal resources that prevent substance abuse.

\section{CONCLUSIONS}

The psychological prevention of addictive behaviour among adolescents involves a number of important stages, such as the diagnostic and awareness-raising phases, as well as personal growth trainings with elements of correcting adolescents' individual personality traits and behaviours. Two models of primary prevention training programmes for adolescents prone to addictive behaviour are most commonly used: sociopsychological competence development programmes and life skills training schemes. Preventive work in the counselling process is most effective in the form of influencing the conditions and causes of addictive behaviour at the early stages.

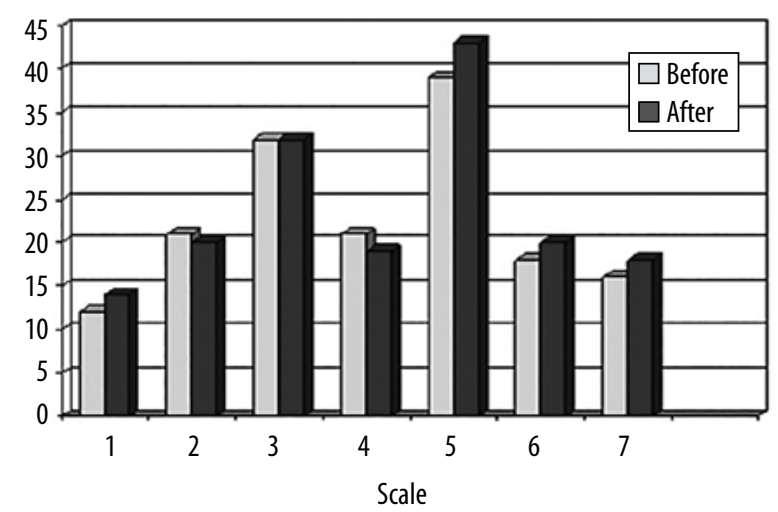

Fig. 4. Diagnostic results of adolescents' predisposition to addictive behaviour in the control group by Oryol's "Methods for the diagnosis of adolescents' predisposition to deviant behaviour" before and after the implementation of the experimental programme 
The choice of the form of psychological counselling depends on the characteristics of adolescence and on the severity of affective problems. The most attractive option for adolescents is the group form of psychological preventive work. Especially effective are group psychological consultations that can involve model situations, creative tasks, training exercises aimed at finding alternatives to deviant (addictive) behaviour, as well as exercises leading to the expansion of opportunities in social life due to desistance from addictive behaviour.

The main objectives of group consultations with adolescents prone to addictive behaviour are as follows: fostering the ability to navigate their own and other people's emotions, developing a sense of empathy; suggesting activities that are an alternative to addictive behaviour; promoting a healthy lifestyle; developing skills to resist adverse environmental factors; activating adolescents' personal resources; and reducing the negative effects of addictions.

The effectiveness of the psychological prevention of adolescent addictive behaviour is determined by the degree of compliance with the principles of expediency and continuity of its implementation, as well as planning and conducting of the group forms of psychological counselling with adolescents, taking into account their age characteristics. This is evidenced by a comparative analysis of the results of the study before and after the implementation of experimental programme in the experimental and control groups.

After the implementation of the programme for the psychological prevention of adolescents' predisposition to addictive behaviour by means of the group form of psychological counselling, significant changes were observed in the experimental group (using statistical analysis), with some positive dynamics of the following indicators:

- the number of adolescents who began to choose a constructive conflict behaviour "cooperation" strategy in conflict resolution increased, and the number of adolescents selecting such conflict behaviour strategies as "competition," "avoidance" and "adaptation" decreased;

- the number of adolescents with a high and medium level of self-regulation increased, and the number of adolescents with a low level of self-regulation significantly decreased;

- the high levels of anxiety, frustration and aggressiveness in adolescents declined significantly;

- the adolescents' predisposition to addictive behaviour decreased, along with reduced predisposition to self-harming and self-destructive behaviour, to aggression and violence, to delinquent behaviour, as well as to the violation of norms and rules.

In the control group, there were no significant positive changes, which shows that the individual form of psychological counselling for adolescents in the framework of the prevention of addictive behaviour was ineffective. This is evidenced by the results of our statistical analysis using the criterion of the concordance of event frequency: no sig-
The results of the study confirm the experimental hypothesis that the group form of psychological counselling for adolescents is one of the most effective means of psychological prevention of adolescent addiction behaviour.

\section{Conflict of interest}

The authors do not report any financial or personal connections with other persons or organisations, which might negatively affect the contents of this publication and/or claim authorship rights to this publication.

\section{References}

Abdrakhmanova ShZ, Adayeva AA, Slazhneva TI et al.: Mental wellbeing, positive health outcomes and risk behaviors among immigrant adolescents in Kazakhstan. Medicine (Almaty) 2019; 7-8 (205-206): 2-9.

Ansari H, Mohammadpoorasl A, Shahedifar $\mathrm{N}$ et al.: Internet addiction and interpersonal communication skills among high school students in Tabriz, Iran. Iran J Psychiatry Behav Sci 2017; 11 (2): e4778.

Battakova ZhE, Tokmurziyeva GZh, Akimbayeva AA: [Monitoring the prevalence of behavioural risk factors in the Republic of Kazakhstan]. National Association of Scientists 2015; 2-8 (7): 16-21.

Bedulina GF: [Formation of a Healthy Lifestyle: Computer Technologies in the Preparation of Peer Coaches]. Lazurak, Minsk 2008.

Bibekova ZhB, Zarovnyy KV, Karazhigitova SM: [Epidemiological and clinical data on alcohol psychoses in the Karaganda region]. Narcology 2020; 19 (8): 33-40.

Brown SA, Brumback T, Tomlinson K et al.: The National Consortium on Alcohol and NeuroDevelopment in Adolescence (NCANDA): a multisite study of adolescent development and substance use. J Stud Alcohol Drugs 2015; 76: 895-908.

Chen CM, Yi HY, Faden VB: Surveillance Report \#101: Trends in Underage Drinking in the United States, 1991-2013. U.S. Department of Health and Human Services, Rockville, MD 2015. Available from: https://pubs.niaaa.nih.gov/publications/surveillance101/Underage13.pdf [cited: 11 January 2021].

Chukhrova MG: [Modern concepts of behavioural addiction]. Siberian Pedagogical Journal 2014; 5: 105-110.

Chung T, Creswell KG, Bachrach R et al.: Adolescent binge drinking: developmental context and opportunities for prevention. Alcohol Res 2018; 39: 5-15.

Cottone P, Moore CF, Sabino V et al. (eds.): Compulsive Eating Behavior and Food Addiction: Emerging Pathological Constructs. Academic Press, 2019.

Drepa MI: [Internet dependence as an object of scientific reflection in contemporary psychology]. Knowledge. Understanding. Skill 2009; 2: 189-193.

Glebova MV: [Development of anti-drug stability in children with hearing problems]. IZVESTIA: Herzen University Journal of Humanities and Sciences 2011; 129: 157-164.

Goldberg IK, Kutcher AH, Haley HB: Therapeutic Drugs and the Quality of Life. Center for Thanatology and Education, 1998.

Information Agency "Kokshetau Asia": [What drugs do Kazakhstani schoolchildren use?]. 2017. Available from: https://kokshetau.asia/ proisshestviya-mobile/25808-kakie-narkotiki-upotreblyayutkazakhstanskie-shkolniki [cited: 11 January 2021].

Ivanov DV: [Social and psychological determinants of addictive behaviour in teenagers]. Science Vector 2013; 3 (25): 424-426.

Kaliyev MS: [The use of psychoactive substances]. 2019. Available from: https://call-centervko.kz/ru/\%D0\%BD\%D0\%BE\%D0\%B2\% D0\%BE\%D1\%81\%D1\%82\%D0\%B8/2019/05/30/\%D1\%83\%D0\% BF\%D0\%BE\%D1\%82\%D1\%80\%D0\%B5\%D0\%B1\%D0\%BB\%D0 \%B5\%D0\%BD\%D0\%B8\%D0\%B5-\%D0\%BF\%D1\%81\%D0\%B8\% D $1 \% 85 \%$ D0\%BE\%D0\%B0\%D0\%BA \%D 1\%82\%D0\%B8\%D0 
\%B2\%D0\%BD\%D1\%8B\%D1\%85-\%D0\%B2\%D0\%B5\%D1\%89\% D0\%B5\%D1\%81\%D1\%82\%D0\%B2-(\%D0\%BF\%D0\%B0\%D0\%B 2) $/$ ? mode=mobiletmp [cited: 11 January 2021].

Karelin A: [Great Encyclopaedia of Psychological Tests]. Eksmo, Moscow 2007.

Krasnova AA: [Psychological Counselling as a Means of Prevention of Adolescents' Predisposition to Addictive Behaviour]. Master's thesis, SSSPU, Samara 2017.

Kulakov SA: [Psychotherapy and Psychological Prevention of Adolescent Addictive Behaviour]. Gardarika, Saint Petersburg 2003.

Lipunova OV: [Psychology of Deviant Behaviour]. FLINTA, Moscow 2016.

Mendelevich VD: [Guide to Addictology]. Rech', Saint Petersburg 2007.

Mikhaylova AP, Shtrakhova AV: [Eating behavior in norm, in conditions of stress and in the presence of pathology: bibliographic review]. Bulletin of South Ural State University Ser Psychology 2018; 11 (3): 80-95.

Morosanova VI: [Individual Self-Regulation Style: Phenomenon, Structure and Functions in the Arbitrary Activity of a Person]. Nauka, Moscow 2001.

Morozova TA: [Peculiarities of medical and social work with persons who use alcohol and drugs in Kazakhstan]. Medico-social and psychological aspects of the safety of industrial agglomerations: Proceedings of the International Scientific and Practical Conference, February 16-17. UrFU, Ekaterinburg 2016: 48-55.

Okuneva LI, Darbayev DS: [Computer addiction as a basic addiction of modern society]. Bulletin of M. Kozybayev North Kazakhstan State University 2015; 4 (29): 111-115.

Pontes HM, Kuss DJ, Griffiths MD: Clinical psychology of Internet addiction: a review of its conceptualization, prevalence, neuronal processes, and implications for treatment. Neuroscience and Neuroeconomics 2015; 4: 11-23.

Prokhorov AO: [Practical Course on the Psychology of States]. Rech' Saint Petersburg 2004

Rahardjo W: [Self-esteem and internet addiction: overview of metaanalysis]. Buletin Psikologi 2019; 27 (1): 70-86.

Ridder City Portal: [Kazakhstan ranks first among the Central Asian countries in terms of the number of drinking people]. 2019. Available from: https://infor.kz/stati/zdorove-i-medicina/kazahstanzanimaet-pervoe-mesto-sredi-stran-centralnoi-azii-po-kolichestvu-pyuschih-lyudei.html [cited: 11 January 2021].
Rozhkov MI, Kovalchuk MA: [Prevention of Adolescent Drug Addiction]. Vlados, Moscow 2004.

Salarvand S, Bagheri Z, Keshvari M et al.: The prevalence of Internet addiction and its relations to the self esteem and life satisfaction in students of a medical university. Acta Medica Iranica 2018; 56: 392-397.

Satayeva LG: [Prevalence of substance use disorders in the Republic of Kazakhstan and supply of medicines for patients with this pathology]. Journal of Addiction Problems 2013; 5: 86-93.

Schulte EM, Potenza MN, Gearhardt AN: How much does the Addiction-Like Eating Behavior Scale add to the debate regarding food versus eating addictions? Int J Obes (Lond) 2018; 42: 946.

Semenova OYu: [Psychophysiological and Psychological Characteristics of Adolescents at Risk of Different Types of Addictions]. Abstract of the author's doctoral dissertation, Saint Petersburg 2012.

Shilova TA: [Prevention of Alcohol and Drug Dependence among Adolescents at School]. Iris-press, Moscow 2004.

Throuvala MA, Griffiths MD, Rennoldson M et al.: School-based prevention for adolescent Internet addiction: prevention is the key. A systematic literature review. Curr Neuropharmacol 2019; 17: 507-525.

Wenzel KR, Weinstock J, McGrath AB: The clinical significance of food addiction. J Addict Med 2020; 14: e153-e159.

World Health Organization: Adolescents drink less, although levels of alcohol consumption are still dangerously high. 2018. Available from: https://www.euro.who.int/ru/media-centre/sections/pressreleases/2018/adolescents-drink-less,-although-levels-of-alcoholconsumption-are-still-dangerously-high [cited: 11 January 2021].

World Health Organization: Total consumption, three-year average with 95\% CI by country. Global Health Observatory data repository. 2020. Available from: https://apps.who.int/gho/data/node. main.A1036 [cited: 11 January 2021].

World Health Organization Collaborative Cross-National Survey: HBSC/WHO report, Spotlight on adolescent health and wellbeing, launches. 2020. Available from: http://www.hbsc.org/news/ index.aspx?ni=6144 [cited: 11 January 2021].

Yarysheva AA: [Imbalance of Identity as a Determinant of Predisposition to Addictive Behaviour of High-School Children]. Abstract of the author's doctoral dissertation, Kemerovo 2012.

Young KS, de Abreu CN (eds.): Internet Addiction: A Handbook and Guide to Evaluation and Treatment. John Wiley \& Sons, Hoboken, NJ 2011. 